\title{
Molecular and Cellular Alterations in Down Syndrome: Toward the Identification of Targets for Therapeutics
}

\author{
Nicole Créau \\ Unité de Biologie Fonctionnelle et Adaptative (BFA), Sorbonne Paris Cité, Universite Paris Diderot, \\ EAC4413 CNRS, 75205 Paris Cedex 13, France \\ Correspondence should be addressed to Nicole Créau, creau@univ-paris-diderot.fr \\ Received 3 February 2012; Revised 18 April 2012; Accepted 19 April 2012 \\ Academic Editor: Hansen Wang \\ Copyright ( 2012 Nicole Créau. This is an open access article distributed under the Creative Commons Attribution License, which \\ permits unrestricted use, distribution, and reproduction in any medium, provided the original work is properly cited. \\ Down syndrome is a complex disease that has challenged molecular and cellular research for more than 50 years. Understanding \\ the molecular bases of morphological, cellular, and functional alterations resulting from the presence of an additional complete \\ chromosome 21 would aid in targeting specific genes and pathways for rescuing some phenotypes. Recently, progress has been \\ made by characterization of brain alterations in mouse models of Down syndrome. This review will highlight the main molecular \\ and cellular findings recently described for these models, particularly with respect to their relationship to Down syndrome \\ phenotypes.
}

\section{Introduction}

Down syndrome (DS) is the most frequent human aneuploidy (1/800 births). DS is characterized, in part, by cognitive impairment, which is present to some degree of severity in all affected individuals [1], and by neuropathological alterations similar to those observed in the brains of Alzheimer's disease patients (over 40 years in DS) [2-4]. Specific deficits of the nervous system in DS individuals affect learning, memory, language, and movement [5-8]. These deficits are associated to alterations in volume, in grey matter density and altered neuronal circuits of different regions of the brain [9-13]. DS typically results from the presence of three complete copies of human chromosome 21 (trisomy 21, T21) [14]. Due to the presence of this extra copy of chromosome 21 (HSA21), DS phenotypes are expected to be associated with a gene dosage effect: genes on HSA21 are present in three copies rather than two, leading to 50\% overexpression (or 1.5-fold expression levels). Transcriptome and proteome studies have shown that, indeed, a global gene dosage effect is present; however, interestingly, expression of a number of trisomic genes varies: some are compensated (near 1), while others are underexpressed (less than 1) or highly overexpressed (more than 1.5). These changes may vary depending on the cellular component and likely result from gene or protein interactions in pathways or in protein complexes (e.g., complex subunits). These variations have been observed in T21 as well as in different organs of mouse models of DS and as a result of aging [15-21]. Thus, defining which HSA21 genes (or murine orthologs) are particularly responsible for disease phenotypes is crucial: identifying the molecular and cellular variations in conjunction with overexpression will help determine their associations with the phenotype and aid in testing potential molecules for phenotypic rescue.

\section{Mouse Models of DS}

Mouse models have been critical to our understanding of the molecular genetics of DS. Several models have been constructed: some have an additional copy of a chromosome segment orthologous to HSA21 [22, 23], others have additional copies of individual genes from HSA21 or their mouse orthologs $[24,25]$. Though more recent models have increased our understanding of the consequences of adding one copy of a specific gene or a segment containing multiple genes, the most extensively studied models are the Ts65Dn [22] and Ts1Cje [23] mice, which carry large segmental trisomies for mouse chromosome 16 (MMU16) (Figure 1). These models recapitulate several phenotypes of 


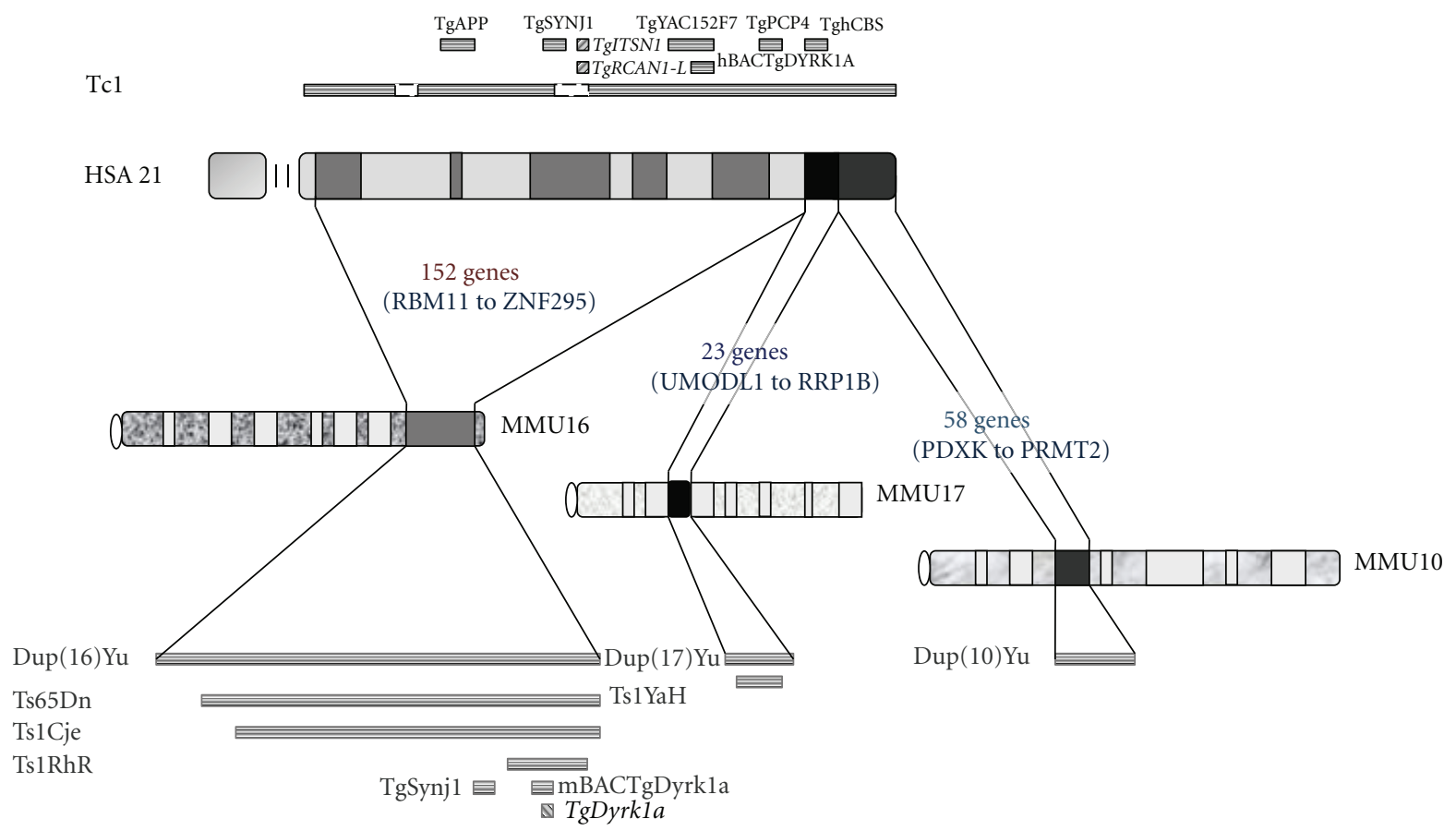

FIGURE 1: HSA21 (with main cytogenetic bands) and its ortholog segments in the mouse genome (MMU16, MMU17 and MMU10) are indicated. Main mouse models and those reported in this review are indicated in black for human genes, and in gray for mouse genes. Models with cDNA constructs are indicated in italics. Representation of their localisation is not to scale. Tc1 [32]; TghAPP [33]; TgSYNJ1 [54]; TgITSN1 [55]; TgRCAN1-L [56]; TgYAC152F7 [34]; hBACTgDYRK1A [24]; TgPCP4 [38]; TghCBS60.4 [57]; Ts65Dn [22]; Ts1Cje [23]; Ts1RhR [58]; TgSynj1 [54]; TgDyrk1a [59]; mBACTgDyrk1a [25]; Dup(16)Yu, Dup(17)Yu and Dup(10)Yu [29, 31]; Ts1Yah [30].

DS, including reduced brain volume, significant learning and memory impairment, and altered synaptic plasticity measured in hippocampal long-term potentiation (LTP). However, recent investigations into the exact gene composition of these models have shown that, in addition to the duplicated segment of MMU16, Ts65Dn, which results from a translocation onto MMU17, contains a duplication for proximal genes of MMU17 and Ts1Cje contains a deletion of a 7-gene span of MMU12 [26-28]. More recent trisomic models [29-31], constructed using the Cre/loxP-mediated chromosome engineering strategy, have integrated only segments of the mouse chromosomes orthologous to HSA21MMU16, MMU17, and MMU10 (Figure 1)-eliminating any potential confounding effects from additional genetic aberrations. Another model, Tc1, is a transchromosomic model transmitting a copy of a portion of HSA21 spanning over $75 \%$ of the original chromosome [32]. The human genes present on this chromosome are, indeed, expressed in the mouse, confirming that specific models may bear either a human or mouse gene, as previously demonstrated with YACs containing human genes $[33,34]$. Interestingly, the Tc1 model may also be useful for evaluation of effects of T21 mosaicism because the transchromosome appears to be retained in only $50-60 \%$ of Tc1 adult brain cells [35]. In fact, Papavassiliou et al. [36], in studying the rate of T21+ cells in the buccal mucosa and lymphocytes of individuals with T21 mosaicism, found a positive correlation between patient IQ range and percentage of T21+ cells in their tissues. Thus, the presence of trisomy in at least $50 \%$ of brain cells may have strong implications for cognitive development.

Transgenic models introducing a specific HSA21 gene or murine ortholog, and for which molecular and cellular studies have been performed, are presented along with trisomic models in Figure 1 and Tables 1 and 2. Tables 1 and 2 summarize the main studies identifying molecular and cellular changes in these models.

\section{DS Transcriptome}

Gene expression studies have provided much-needed insight into global expression changes occurring in DS. In particular, microarrays have been employed to determine the transcriptome of cells and even brain structures. Ts1Cje and Ts65Dn transcriptomes were analyzed at various developmental timepoints (see Table 1). Changes in transcript levels were observed for genes in three copies, mirroring copy number (i.e., near 1.5-fold). However, more specific analyses of expression changes, as in the cerebellum of Ts65Dn [44], suggest that the genetic backgrounds of trisomic mice may impart individual variations onto expression changes. Further, such inter-individual variations are observed at the protein level [52]. Interestingly, in Tc1 mice genes from HSA21 are expressed at embryonic day (E) 14.5, indicating that these genes are transcribed during mouse embryonic development [32]. Recall that this model leads to a mosaic composition of adult organs with cells containing or not 
TABLE 1: Significant quantitative transcript variations observed in the DS mouse models (trisomics and transgenics, see Figure 1). Results are classified from top to bottom with increasing age of the mice studied: age in embryonic days (E), postnatal days (d) and month (m). Names in bold for genes present in 2 copies. Transcriptome methods used: C (cDNA arrays); N (Northern); M (microarrays); Q (quantitative-RTPCR); R (RT-PCR). Gene names are indicated according to gene nomenclature (Gene Cards: http://www.genecards.org/).

\begin{tabular}{|c|c|c|c|c|c|c|c|c|c|}
\hline Brain structures & Models & Age & Up & Down & Method & $\begin{array}{c}\text { Additional } \\
\text { comment }\end{array}$ & Target & Rescue & References \\
\hline $\begin{array}{l}\text { E11-E13 } \\
\text { telencephalon, } \\
\text { mesencephalon } \\
\text { + diencephalon }\end{array}$ & TgYAC152F7 & $\begin{array}{l}\text { E11.5, } \\
\text { E12.5, } \\
\text { E13.5 }\end{array}$ & Dyrk1a & & $\mathrm{Q}, \mathrm{M}$ & $\begin{array}{c}\text { Dysregulation of } \\
\text { the Rest } \\
\text { pathway }\end{array}$ & & & {$[37]$} \\
\hline $\begin{array}{l}\text { Embryonic, } \\
\text { brain } \\
\text { hemispheres, } \\
\text { cerebellum }\end{array}$ & Ts1Cje; TgPCP4 & $\begin{array}{c}\text { E11.5, } \\
\text { E14.5, } 4 \mathrm{~m}\end{array}$ & Pcp4 & & Q & & & & {$[38]$} \\
\hline Embryonic total & $\mathrm{Tc} 1$ & E14.5 & - & & $\mathrm{R}$ & $\begin{array}{c}\text { Expression } \\
\text { human genes }\end{array}$ & & & {$[32]$} \\
\hline Embryonic & mBACTgDyrk1a & E14.5 & Dyrk1A & & Q & & & & {$[25]$} \\
\hline Total brain & Ts1Cje & birth & $\begin{array}{c}\text { mean: } \\
1.435\end{array}$ & & M & & & & {$[39]$} \\
\hline Cerebellum & Ts1Cje & birth & Ptch, Shh & & $\mathrm{M}$ & & & & {$[26]$} \\
\hline Cortex, brain & Ts65Dn & $8 \mathrm{~d}$ & Vip, Vipr1 & & Q & & & & {$[40]$} \\
\hline Total brain & Ts65Dn & $1 \mathrm{~m}$ & $\begin{array}{l}62 \% \text { of } \\
3 \text {-copy } \\
\text { genes }\end{array}$ & & Q & & & & {$[18]$} \\
\hline $\begin{array}{l}\text { Hippocampus, } \\
\text { frontal cortex, } \\
\text { substantia nigra }\end{array}$ & Ts65Dn & $78-92 \mathrm{~d}$ & Kcnj6 & & Q & & & & {$[41]$} \\
\hline Hippocampus & TgYAC152F7 & $3 \mathrm{~m}$ & Dyrk1a & $\begin{array}{l}\text { Bdnf, } \\
\text { Trkb }\end{array}$ & Q & & Dyrk1a & Bdnf, Trkb & {$[42]$} \\
\hline Hippocampus & TS65Dn & $3 \mathrm{~m}$ & $\begin{array}{c}\text { Gart, } \\
\text { Ifnar2, } \\
\text { Kcnj6, } \\
\text { Itsn1, } \\
\text { Hcls, Sod1 } \\
\end{array}$ & & M & & Gabra5 & Bdnf & {$[43]$} \\
\hline Cerebellum & Ts65Dn & $3-4 \mathrm{~m}$ & $\begin{array}{c}\text { range } \\
(0.84- \\
2.93) ; \\
\text { mean } 1.45 \\
\end{array}$ & & M & & & & {$[44]$} \\
\hline $\begin{array}{l}\text { Cortex, } \\
\text { midbrain, } \\
\text { cerebellum }\end{array}$ & Ts65Dn & $4 \mathrm{~m}$ & $\begin{array}{c}\text { mean: } \\
1.63,1.3 \\
1.37\end{array}$ & & $\mathrm{C}, \mathrm{M}$ & & & & {$[17]$} \\
\hline Forebrain & Ts65Dn & $4 \mathrm{~m}$ & $\begin{array}{l}\text { App, Sod1, } \\
\text { ApoE }\end{array}$ & & $\mathrm{N}$ & & & & {$[45]$} \\
\hline $\begin{array}{l}\text { Hippocampus } \\
\text { (rescue), } \\
\text { prefrontal } \\
\text { cortex }\end{array}$ & Ts65Dn & $5-6 \mathrm{~m}$ & $\begin{array}{c}\text { mir155, } \\
\text { mir802, } \\
\text { Mef2c }\end{array}$ & $\begin{array}{l}\text { Creb1, } \\
\text { Mecp2 }\end{array}$ & Q & & $\begin{array}{l}\operatorname{mir}-155 \\
\operatorname{mir}-802\end{array}$ & $\begin{array}{l}\text { Mecp2, } \\
\text { Mef2c, } \\
\text { Creb1 }\end{array}$ & {$[46]$} \\
\hline $\begin{array}{l}\text { Brain } \\
\text { hemispheres }\end{array}$ & Ts65Dn & 4 to $12 \mathrm{~m}$ & $\begin{array}{l}\text { App, Sod1, } \\
\text { Dyrk1a }\end{array}$ & & Q & $\begin{array}{c}\text { increase with } \\
\text { age }\end{array}$ & & & {$[21]$} \\
\hline Brain & Ts65Dn & $6-7 \mathrm{~m}$ & & Gfap & Q & & & & {$[47]$} \\
\hline $\begin{array}{l}\text { Hippocampus, } \\
\text { cortex, raphe } \\
\text { nuclei }\end{array}$ & Ts65Dn & $9.5 \mathrm{~m}$ & Vip, Vipr1 & & Q & & & & {$[48]$} \\
\hline Hippocampus & Ts65Dn & $10 \mathrm{~m}$ & & Bdnf & Q & & Nmdar & Bdnf & {$[49]$} \\
\hline Total brain & Ts65Dn & $11 \mathrm{~m}$ & $\begin{array}{c}47 \% \text { of } \\
3 \text {-copy } \\
\text { genes }\end{array}$ & & Q & & & & {$[18]$} \\
\hline
\end{tabular}


TABle 1: Continued.

\begin{tabular}{|c|c|c|c|c|c|c|c|c|c|}
\hline Brain structures & Models & Age & Up & Down & Method & $\begin{array}{c}\text { Additional } \\
\text { comment }\end{array}$ & Target & Rescue & References \\
\hline $\begin{array}{l}\text { Hippocampal } \\
\text { CA1 }\end{array}$ & Ts65Dn $(m+f)$ & $12-24 \mathrm{~m}$ & Htr2c & $\begin{array}{c}\text { Cdk5, } \\
\text { Ntf3 }\end{array}$ & Q & & & & {$[50]$} \\
\hline $\begin{array}{l}\text { Medial septum, } \\
\text { hippocampus }\end{array}$ & Ts65Dn & $18 \mathrm{~m}$ & App & & Q & & & & {$[51]$} \\
\hline
\end{tabular}

HSA21, detecting the molecular consequences in adults at the transcriptional level may be more difficult. Interestingly, Tc1 mice have impaired short-term memory but normal long-term memory [35]; both features are affected in Ts65Dn mice [53]. These contrasted phenotypes in adult mice suggest that part of the functional alterations in DS results from strong modifications in proliferation and/or differentiation steps of neural components of various brain structures - processes that are established during embryogenesis. Notably, however, the absence of several genes on the human chromosome transmitted in Tc1 may also influence the functionality of the adult brain (Figure 1).

More recent evidence indicates that alternative splicing may play a role in differentiating the brain transcriptome in DS mouse models as well as in DS. Proteins involved in the splicing machinery are modulated and alternative exons of key synaptic transcripts (neuroligins, TrkB, AChE, Mapt) can be expressed, suggesting a different control of the transcriptome in the disease state. Modulated splicing factors (ASF, Srp55, Srp75, Srp30, SC35) were identified at the global protein level or at the phosphorylation level depending on the brain regions explored as well as a result of aging. Notably, at least one HSA21 gene appears to be responsible for dysregulation via splicing factor phosphorylation: Dyrk1A. This proline-directed serine/threoninekinase colocalizes with some of these splicing factors and, further, regulates biogenesis of the splicing speckle compartment [60-62]. In adults with DS, Dyrk1a overexpression appears related to overexpression of the $3 \mathrm{R}$ isoform transcript of microtubule-associated protein tau (Mapt), which is predominant in neurofibrillary tangles, suggesting a new role for Dyrk1a in neuronal degeneration [61, 63-65].

In addition to protein-coding RNAs, several functional RNAs do not lead to the translation into a protein (noncoding RNA). MicroRNAs (miRNA) belong to the small noncoding RNAs class and have been shown acting on the regulation of translation of gene transcripts either by degradation or repression, thus influencing the content of the proteome. Mounting evidence suggests that miRNAs affect brain development and function [66]. Five miRNAs are transcribed from HSA21, three of which are clustered [46]. HSA21 miRNAs (miR-99a, let-7c, miR-125b-2, miR-155, and miR-802) are overexpressed in the DS brain from fetal to adult stages $[46,67,68]$. In the Ts65Dn mouse model, only miR-155 and miR-802 (both in 3 copies) have been found to be overexpressed in brain [69]. The authors found also that the transcription of the methyl-CpG-binding-protein (Mecp2) gene, which is mutated in Rett syndrome, is decreased. Intracerebroventricular injection of Ts65Dn with antisense
RNA for these two miRNAs (antagomirs) normalizes the expression of Mecp2 and Creb (cyclic AMP responsive element binding protein)as well as the Mecp2-regulated gene Mef2c (increased in Ts65Dn) [69]. Other possible involvement of miRNAs in brain alterations of DS and mouse models require further investigation [70].

\section{DS Proteome}

Alterations in the transcriptome in DS is expected to have direct implications on the proteome. The brain proteome has been studied using different quantification methods, but its modulations are more difficult to approach on a large scale. Quantitative immunohistochemistry is complementary to these approaches, since it can reveal which cells may be more affected by protein expression changes. Indeed, it is necessary to determine whether any fluctuations in protein expression result from changes at the cellular level or changes in the proportion of cells expressing the protein(s). Current research targeting potential pathways have led to an increase in studies identifying the proteome changes within specific brain structures in DS models.

Table 2 recapitulates significant protein changes (up or down) observed in the trisomic and transgenic mice in function of age and brain structures. Interestingly, these data show that the proteins level even in the same mouse model may increase with age (App and Sod 1 - which are in 3 copies), may depend on the brain structures (Synaptophysin (Syp) up in cortex versus down in hippocampus; Gaba-b receptor 2 (Gabbr2) up in hippocampus versus down in thalamus) or may be increased from early stages to adult (Map2, $\mathrm{Ntf} 3$ ), though all developmental stages are not yet studied.

\section{Morphological and Cellular Changes in Brain Structures}

The universal presence of cognitive impairment in DS has made understanding the structural and cellular changes in the DS brain the focus of much research effort. Reduction in cerebellum volume is a feature of Down syndrome and is recapitulated in Ts65Dn and to a lesser extent in Ts1Cje models. Interestingly, changes in volume or cellular density appear to differ between regions of the brain, suggesting that gene dosage differentially affects brain structure development $[9,10,89,90]$. Similarly, enlargement of the lateral ventricle, another alteration in brain morphology, has been observed in both DS and mouse models of DS, specifically Ts1Cje, Ts2Cje [91], Ts65Dn, and mBACTgDyrk1a [25]. 


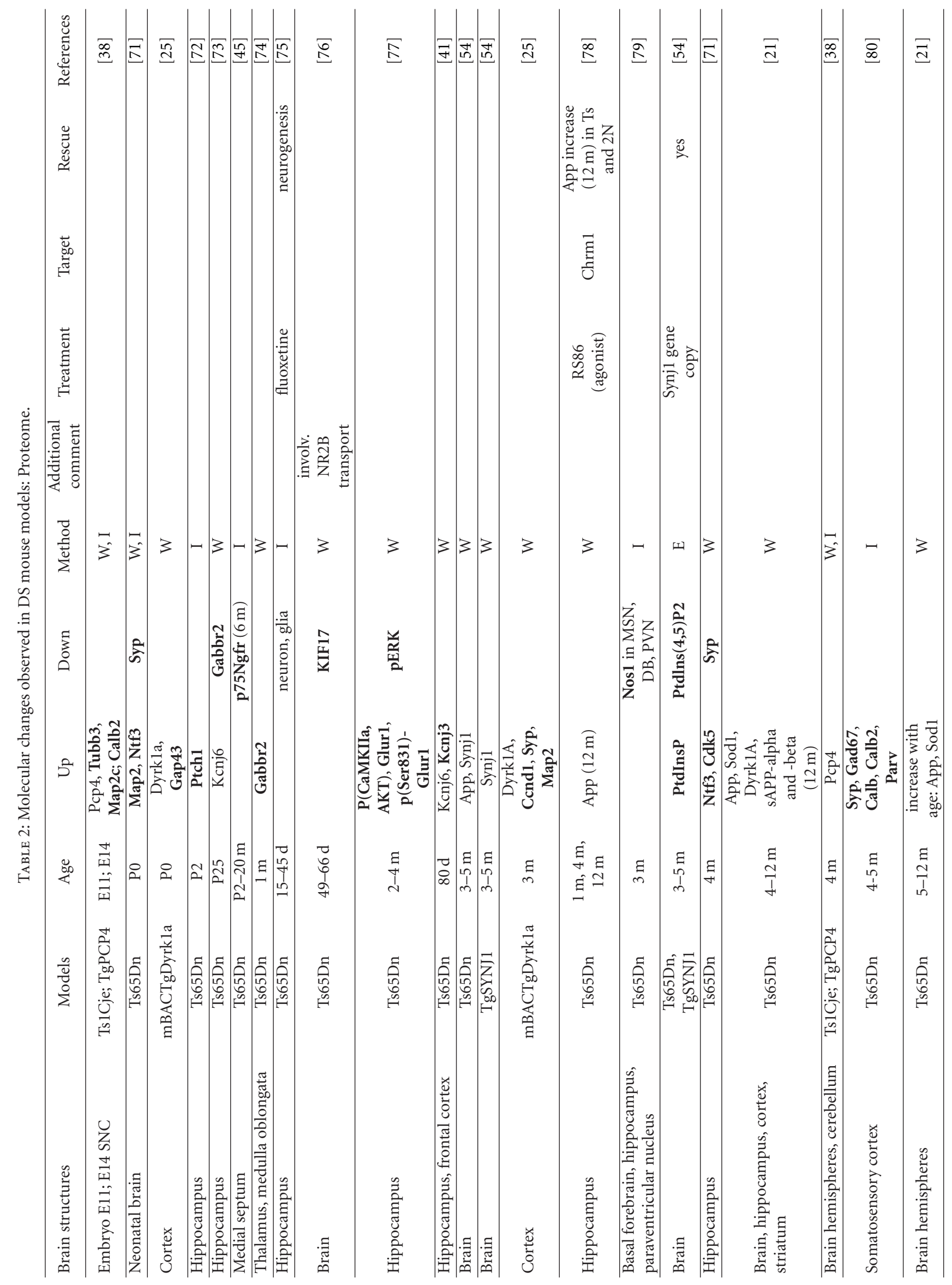




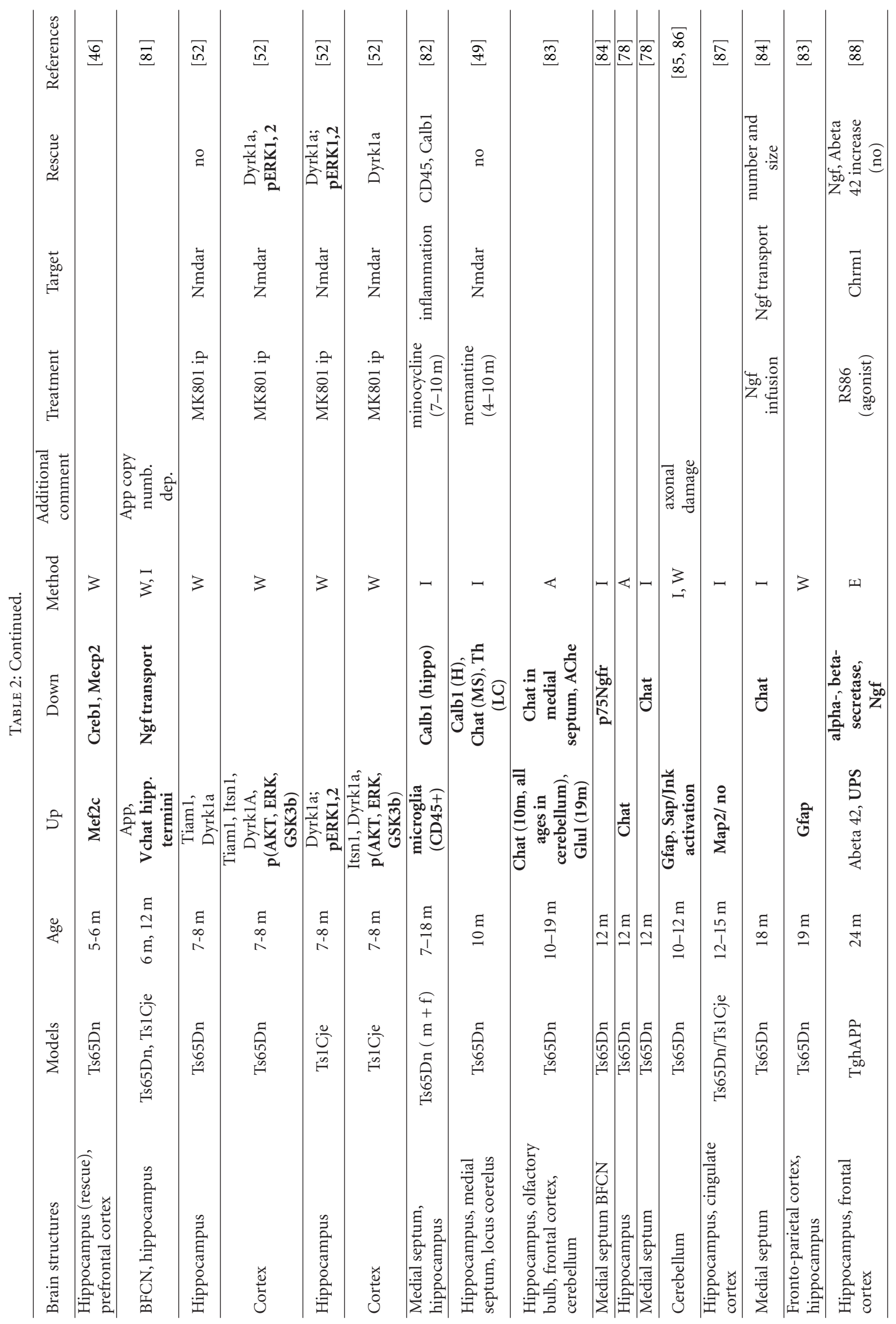


Cell proliferation is also altered in DS and in mouse models, suggesting a relationship between alterations in volume and altered cell numbers in brain structures. In cortex, hippocampus, and cerebellum, region volume and neuronal populations are affected [58, 92-96]. These defects in proliferation alter the neuron as well as the astrocyte number and percentage. Recently, proliferation impairment in neural cell precursors of Ts65Dn was shown to involve inhibition of the hedgehog pathway [72]. This finding extends those of Roper et al. [97], who linked hedgehog to decreased granular cell progenitor (GCP) production in the cerebellum of Ts65Dn. Sonic hedgehog $(S h h)$, produced by the cerebellar Purkinje cell, typically activates GCP proliferation during cerebellar development, but this pathway is defective in DS models. Similarly, a defect in Shh mitotic response is present in neural crest progenitors of these mice [98]. Inhibition of the hedgehog pathway can occur through overexpression of a fragment of amyloid precursor protein (App, in 3 copies in the Ts65Dn), AICD (App intracellular domain). Through increased binding of AICD to the Ptch1 (Patched, SHH receptor) promoter and histone hyperacetylation, Ptch1 is overexpressed [72]. However, silencing of Ptch1 restores proliferation of neural cell precursors. Indeed, AICD has been shown to act as a transcriptional regulator for its own gene (App) as well as other genes [99]. Reduced cerebellar volume also occurs in Ts1Cje mice (2 copies of App), but to a lesser extent than in Ts65Dn ( 3 copies of App), suggesting that other 3-copy genes contribute to the proliferation defect through the Shh receptor Ptch1 [26] or other molecules.

Notably, these proliferation defects may be associated with the surprising lack of medulloblastoma and neuroblastoma tumors observed in Down syndrome [100-102]. In DS models, several genes involved in the regulation of the cell cycle, namely, cell-cycle-dependent kinases p21Cip1 [103] and p27Kip1 [104, 105], are differently affected and induce a dysregulation of the cell cycle. These proteins as well as Ptch1, the receptor for Shh [72], have been shown to be important players in medulloblastoma induction [106]. Thus, the alteration in neural proliferation, while likely contributing to cognitive impairment in DS, may protect against these type of tumors. Additionally, increased Dyrk1a [107] and Pcp4 [38, 108, 109] expression are associated with premature neuronal differentiation at early embryonic stages, which may also guard against these tumors by driving neurons to a more mature state.

Interestingly, increased dosage of murine Dyrkla leads to an increase in neurons and glial cells in the thalamus VPLVPN while other structures, like the somatosensory cortex, though increased in volume, do not show any change in the numbers of these cellular components [25]. Thus, proliferation may be differentially affected in particular regions and cell types during development, as has been visualized in the DS brain $[10,110]$.

Adult neurogenesis occurs at two major sites in the brain: the subventricular zone of the lateral ventricule and the subgranular zone of the dentate gyrus of the hippocampus (human and mouse). Though the physiological relevance of adult neurogenesis is still under debate, it may have strong implication in new acquisition of memory. Adult neurogenesis is impaired in Ts65Dn hippocampus [111] and can be reversed by treatment with fluoxetine, an inhibitor of serotonin (5-HT) reuptake [112]. Recent experiments using the same molecule rescued neurogenesis in Ts65Dn not only in hippocampus but also other structures (striatum, neocortex) and involved the rescue of expression of the neurotrophic factor BDNF [75], which is crucial for neuron survival. Indeed, BDNF levels (RNA and protein) depict a complex situation in DS that may result partly from a newly identified mechanism acting in brains of DS models: regulation of local translation [113]. BDNF RNA levels are decreased in DS and mouse models, but circulating levels of BDNF are higher in DS $[42,114,115]$. In Ts1Cje, increased BDNF release in the hippocampus occurs through different regulators of synaptic local translation, suggesting a more fine-tuned regulation of this neurotrophic factor. Further, the new hypothesis proposed by Troca-Marín et al. [113] of a positive-feedback loop involving BDNF and the Akt-mTOR pathway suggests new avenues for treatment. This type of regulation may involve other molecules important for brain function, as has already been shown for Dscam [116]—which occurs in 3 copies in the mouse models - and still needs to be explored.

Other molecules and pathways contributing to DS neuropathology have been extensively studied. For example, Map2, a microtubule-associated protein present in the soma and dendrites of mature neurons, is increased in hippocampus and cingulate cortex of Ts65Dn, independent of age [71, 87]. Map2 immunolabeling reveals thicker, shorter, and lesstapered dendrites in aged Ts65Dn adult neurons. Further, during embryonic cell differentiation in culture, abnormal neurite branching was observed in neurons of fetal T21 [117] and $\mathrm{Tc} 1[118]$, combined with an increase in secondary to primary dendrites. Abnormal dendrites have been previously observed during early development in DS cortex; the overdevelopment of dendritic trees in the visual cortex of DS patients at birth, despite dendritic atrophy later during infancy $[119,120]$, suggests that temporally different mechanisms may contribute to abnormal maturation of neurons in DS. Though different 3-copy genes might contribute to these changing phenotypes $[38,59,121]$, the mechanisms of altered cytoskeletal dynamics remain unexplained.

Another neuronal phenotype in DS is the excitationinhibition imbalance shown to play a central role in brain malfunction; reducing overinhibition represents a current goal for ameliorating cognitive dysfunction $[122,123]$. Overinhibition may result from an increase in inhibitory neurons $[80,95]$, an increase in inhibitory synapses $[124,125]$, an increase in efficiency of inhibitory synapses [126], an increase in stimulation of GABAergic ouput neurons [127], or a decrease in these excitatory components [128]. Moreover, in relation to Girk2 overexpression (Kcnj6 in 3 copies) which regulates the GABA-B receptor at dendrites, the balance between GABA-B and GABA-A inhibition is altered in Ts65Dn hippocampus [41, 73, 129]. In Ts65Dn cortex, excitatory neurons exist in the same proportions in control and Ts65Dn brains throughout development; interneurons, however, are increased in Ts65Dn brains. Further, these interneurons show an increased excitability in basal 
conditions [95]. Reducing copy numbers of Olig1 and Olig2 transcription factors required for oligodendrocyte specification and differentiation [130], rescues the number of cortical interneurons of Ts65Dn [95]. Finally, additional circuitries of neurotransmitter release as well as neuropeptide signaling are impaired ([54, 79, 131, 132]; Table 2).

Though the global composition of Ts65Dn synapses does not differ from controls reduced CaMKIIalpha and increased peptide phosphorylation, potentially important for synaptic function, have been found; synaptojanin 1 (Synj1), which is important for synaptic vesicle recovery and is triplicated in Ts65Dn, is also increased [133]. Additionally, spine morphology and spine density differ [134, 135], but the global level of synaptophysin, a marker of presynaptic vesicles, appears reduced [71]. Decreased spine density has been observed in Ts65Dn hippocampus and temporal cortex [135-137]. Further, synapse enlargement is present in hippocampus, with an associated decreased length of spine neck [135]. Similarities are evident in spine morphology between Ts1RhR [58], Ts1Cje, and Ts65Dn, but with increased severity of phenotype with increased number of genes in 3 copies $[134,138]$. Moreover, the trisomy in Ts1RhR is sufficient to induce a decreased average in spine density in the fascia dentata [138]. Finally, endocytosis may be altered by increased levels of Itsn1 [55, 139], Dyrk1A [140], Synj1 [141], and interaction with other genes in 3 copies [142]. Together, these anomalies may lead to altered synaptic plasticity, as visualized at the level of hippocampal LTP, and likely regulate learning processes.

Glial cells are another structurally and functionally important component of the brain, serving as support and as regulators of synapse connectivity; they are also present at the blood-brain barrier. Glial fibrillar acidic protein (GFAP) is commonly used to identify these cells. During early development in DS hippocampus and frontal lobe, an increase in GFAP-positive cells is observed [143, 144], together with a more mature morphology [144]. This may result from a preference for glial cell production over neuron production, as seen during the differentiation of neural precursor cells $[117,145-148]$. An increase in glial cells has been identified in the Ts65Dn hippocampus during early postnatal development [149]. However, in adult Ts65Dn brain, a decrease in GFAP transcript was observed [47]. Moreover, dysfunction of Ts65Dn astrocytes [40] coupled with an increase in betacatenin in the microvessels of Ts65Dn brain $[150,151]$, two important components of the brain-blood-barrier, suggest that its function might be altered.

Interestingly, in aged DS brains, a reduced glial cell number has been observed in the cortex [152], and alterations in the morphology of astroglial cells develops with age [153]. Further, increased GFAP in the frontoparietal cortex and hippocampus of aged Ts65Dn mice revealed gliosis [83]. Thus, altered glia may play a role in the modified functionality of brains of DS mouse models. Notably, alterations in Purkinje axons in the cerebella of Ts65Dn have been observed from 10 months of age, while astrogliosis appears later $[85,86]$. These results suggest that the Ts65Dn cerebellum is not protected against neuronal degeneration, which may be detected earlier by specific modifications of neuronal properties.
Finally, identification of aging processes related to Alzheimer's disease pathology are under investigation in DS models. APP has been suspected as a major player in this pathology and increased copy number of APP in human is associated with Alzheimer's disease [154]. Other genes on HSA21 may either protect against or enhance the effects of the increase in APP $[21,64,65]$. Aged Tc1 mice (18 months) have an increase in tau phosphorylation and neurofibrillary tangles, features not present in young animals. Further, a correlation with the level of Dyrk1A was found, but only in aged mice [65]. In this model, human proteins like APP, SYN1, ITSN1, and RCAN1 may be absent, suggesting they do not play a role in that process [35]. Transgenic mice with a copy of the entire APP [33] or SYNJ1 [54] gene have been already constructed, but mice transgenic for ITSN1 and RCAN1 were constructed with heterologous promoters. Thus, although elevated phospho-tau was observed in transgenic TgRCAN1-L [56] mice, confirmation in a model with the entire gene is needed to further understand the role of these genes in Alzheimer's disease pathology.

\section{Genes and Pathways Targeting}

Thanks to these rapid advances in understanding the specific brain alterations in DS, therapeutic approaches are being developed. The first therapeutic assay targeted the specific loss of basal brain cholinergic neurons (BFCN) observed after 6 months in Ts65Dn. This specific loss, due to altered transport of nerve growth factor (NGF), was rescued by infusion of NGF [84], demonstrating the potential for phenotype reversal. As excitation-inhibition imbalance has emerged as a strong target, recent approaches have targeted the potential pathways at the roots of the observed overinhibition. Fernandez et al. [123], by using an inhibitor of the GABA-A receptor (pentylenetetrazole, PTZ), reversed the phenotype of Ts65Dn, confirming that GABA, the major inhibitory neurotransmitter of the central nervous system, is involved. Though multiple approaches are currently being tested (see Table 1), only two recent approaches have tried to identify_on a large scale-correlations between molecular changes and behavioral changes induced by a therapeutic molecule, in adults of DS models.

Braudeau et al. $[43,155]$ analyzed the transcriptome of mice submitted to memory processing using the Morris water maze paradigm following treatment with an inhibitor of the GABA-alpha5 receptor, the GABA-alpha5 promnesiant inverse agonist (alpha5IA). The GABA-alpha5 receptor (Gabra5) is specifically expressed in the hippocampus and, thus, its modulation directly involves hippocampal function. In combination with the expression of early genes, specific 3 copy genes were modulated significantly: 6 transcripts were upregulated (Kcnj6, Sod1, Itsn1, Hcls, Gart, Ifnar2) and 3 were downregulated (App, Kcnj6, Sod1) in Ts65Dn following treatment. Moreover, a set of 5 3-copy genes (including Pcp4, Hmgn1, Cbr1, and Gabpa), as well as BDNF, showed an interaction between genotype and treatment, suggesting a close relationship with this pathway.

Rescue of BDNF expression can also be obtained using green tea polyphenols (PGT) [42] and memantine [49] (see 
Tables 1 and 2). BNDF level rescue is associated with rescue of learning impairments, and thus plays a critical role in our understanding of DS and its potential therapies.

Regulation of the glutamate receptor, NMDAR, may be altered by several genes of HSA21, namely, through the calcineurin pathway. MK-801, a noncompetitive antagonist of NMDAR, may rescue memory retention, in particular, during aging. Locomotor activity of Ts65Dn and TS1Cje was evaluated in relation to different doses of MK-801 which block this receptor with a high affinity [52]. It was given at a dose leading to the same level of induced locomotion in the two strains. Proteins fractions (nuclear, cytosolic and membranous) of hippocampus and cortex were analyzed for their level in phosphorylation for proteins belonging to the Mapk pathway and for Tiam1, Itsn1, and Dyrk1a. Overexpression of these proteins was observed in Ts65Dn and Ts1Cje. Interestingly, a partial decrease in Dyrkla and modified phosphorylation of MAPK proteins was observed in a genotype-specific pattern, suggesting that the genes responsible are at different locations on the trisomic segments [52, Table 2]. Interestingly MK-801 and memantine restore the phospho-mTOR level in Ts1Cje hippocampal dendrites [113]. But it is still to be proved that such treatment will benefit to the Ts65Dn memory impairment [111].

As an noninvasive approach, "environmental enrichment" that combines sensorimotor to social stimulations, may impact at the behavioral and molecular levels $[156,157]$. Standardized methods (starting age, type of stimulation) may be needed to compare the changes observed and help understand why it benefits preferentially to Ts65Dn females.

Finally, molecular and cellular analyses in DS mouse models and DS brains show a clear correlation, though brain regions may vary in their specific features, confirming the utility of mouse models of DS for testing therapeutic treatments [158]. The number of therapeutic approaches in DS mouse models is rapidly increasing, with accompanying tests for behavioral rescue. However, little is known about the molecular and cellular consequences of these treatments; assessing these consequences will be crucial for future research and for any potential translation into the clinic.

\section{Acknowledgments}

The author would like to thank J. M. Delabar, M. C. Potier, and J. Braudeau for helpful discussion during the preparation of this manuscript. This work was supported by the Centre National de la Recherche Scientifique and Fondation Jérôme Lejeune (grant).

\section{References}

[1] B. F. Pennington, J. Moon, J. Edgin, J. Stedron, and L. Nadel, "The neuropsychology of Down Syndrome: evidence for hippocampal dysfunction," Child Development, vol. 74, no. 1, pp. 75-93, 2003.

[2] J. B. Leverenz and M. A. Raskind, "Early amyloid deposition in the medial temporal lobe of young Down syndrome patients: a regional quantitative analysis," Experimental Neurology, vol. 150, no. 2, pp. 296-304, 1998.
[3] M. Nistor, M. Don, M. Parekh et al., "Alpha- and betasecretase activity as a function of age and beta-amyloid in Down syndrome and normal brain," Neurobiology of Aging, vol. 28, no. 10, pp. 1493-1506, 2007.

[4] M. Hanney, V. Prasher, N. Williams et al., "Memantine for dementia in adults older than 40 years with Down's syndrome (MEADOWS): a randomised, double-blind, placebocontrolled trial," The Lancet, vol. 379, no. 9815, pp. 528-536, 2012.

[5] J. O. Edgin, G. M. Mason, M. J. Allman et al., "Development and validation of the Arizona Cognitive Test Battery for Down syndrome," Journal of Neurodevelopmental Disorders, vol. 2, no. 3, pp. 149-164, 2010.

[6] F. A. Conners, M. S. Moore, S. J. Loveall, and E. C. Merrill, "Memory profiles of Down, Williams, and fragile X syndromes: implications for reading development," Journal of Developmental \& Behavioral Pediatrics, vol. 32, no. 5, pp. 405-417, 2011.

[7] K. A. B. Næss, S. A. H. Lyster, C. Hulme, and M. MelbyLervåg, "Language and verbal short-term memory skills in children with Down syndrome: a meta-analytic review," Research in Developmental Disabilities, vol. 32, no. 6, pp. 2225-2234, 2011.

[8] S. Lanfranchi, A. Baddeley, S. Gathercole, and R. Vianello, "Working memory in Down syndrome: is there a dual task deficit?" Journal of Intellectual Disability Research, vol. 56, no. 2, pp. 157-166, 2012.

[9] E. H. Aylward, Q. Li, N. A. Honeycutt et al., "MRI volumes of the hippocampus and amygdala in adults with Down's syndrome with and without dementia," American Journal of Psychiatry, vol. 156, no. 4, pp. 564-568, 1999.

[10] J. D. Pinter, S. Eliez, J. E. Schmitt, G. T. Capone, and A. L. Reiss, "Neuroanatomy of Down's syndrome: a highresolution MRI study," American Journal of Psychiatry, vol. 158, no. 10, pp. 1659-1665, 2001.

[11] C. Rigoldi, M. Galli, C. Condoluci, F. Carducci, P. Onorati, and G. Albertini, "Gait analysis and cerebral volumes in Down's syndrome," Functional Neurology, vol. 24, no. 3, pp. 147-152, 2009.

[12] D. Menghini, F. Costanzo, and S. Vicari, "Relationship between brain and cognitive processes in down syndrome," Behavior Genetics, vol. 41, no. 3, pp. 381-393, 2011.

[13] E. Brunamonti, P. Pani, O. Papazachariadis, P. Onorati, G. Albertini, and S. Ferraina, "Cognitive control of movement in down syndrome," Research in Developmental Disabilities, vol. 32, no. 5, pp. 1792-1797, 2011.

[14] J. Lejeune, M. Gautier, and R. Turpin, "Study of somatic chromosomes from 9 mongoloid children," Comptes Rendus Hebdomadaires des Séances de l'Académie des Sciences, vol. 248, no. 11, pp. 1721-1722, 1959.

[15] E. Aït Yahya-Graison, J. Aubert, L. Dauphinot et al., "Classification of human chromosome 21 gene-expression variations in down syndrome: impact on disease phenotypes," American Journal of Human Genetics, vol. 81, no. 3, pp. 475-491, 2007.

[16] P. Prandini, S. Deutsch, R. Lyle et al., "Natural geneexpression variation in Down syndrome modulates the outcome of gene-dosage imbalance," American Journal of Human Genetics, vol. 81, no. 2, pp. 252-263, 2007.

[17] P. Kahlem, M. Sultan, R. Herwig et al., "Transcript level alterations reflect gene dosage effects across multiple tissues in a mouse model of Down syndrome," Genome Research, vol. 14, no. 7, pp. 1258-1267, 2004.

[18] R. Lyle, C. Gehrig, C. Neergaard-Henrichsen, S. Deutsch, and S. E. Antonarakis, "Gene expression from the aneuploid 
chromosome in a trisomy mouse model of Down syndrome," Genome Research, vol. 14, no. 7, pp. 1268-1274, 2004.

[19] R. Mao, X. Wang, E. L. Spitznagel et al., "Primary and secondary transcriptional effects in the developing human Down syndrome brain and heart," Genome Biology, vol. 6, no. 13, article R107, 2005.

[20] H. E. Lockstone, L. W. Harris, J. E. Swatton, M. T. Wayland, A. J. Holland, and S. Bahn, "Gene expression profiling in the adult Down syndrome brain," Genomics, vol. 90, no. 6, pp. 647-660, 2007.

[21] J. H. K. Choi, J. D. Berger, M. J. Mazzella et al., "Agedependent dysregulation of brain amyloid precursor protein in the Ts65Dn Down syndrome mouse model," Journal of Neurochemistry, vol. 110, no. 6, pp. 1818-1827, 2009.

[22] M. T. Davisson, C. Schmidt, and E. C. Akeson, "Segmental trisomy of murine chromosome 16: a new model system for studying Down syndrome," Progress in Clinical and Biological Research, vol. 360, pp. 263-280, 1990.

[23] H. Sago, E. J. Carlson, D. J. Smith et al., "Ts1Cje, a partial trisomy 16 mouse model for Down syndrome, exhibits learning and behavioral abnormalities," Proceedings of the National Academy of Sciences of the United States of America, vol. 95, no. 11, pp. 6256-6261, 1998.

[24] K. J. Ahn, H. K. Jeong, H. S. Choi et al., "DYRK1A BAC transgenic mice show altered synaptic plasticity with learning and memory defects," Neurobiology of Disease, vol. 22, no. 3, pp. 463-472, 2006.

[25] F. Guedj, P. L. Pereira, S. Najas et al., "DYRK1A: a master regulatory protein controlling brain growth," Neurobiology of Disease, vol. 46, no. 1, pp. 190-203, 2012.

[26] J. Laffaire, I. Rivals, L. Dauphinot et al., "Gene expression signature of cerebellar hypoplasia in a mouse model of Down syndrome during postnatal development," BMC Genomics, vol. 10, article 138, 2009.

[27] A. Duchon, M. Raveau, C. Chevalier, V. Nalesso, A. J. Sharp, and Y. Herault, "Identification of the translocation breakpoints in the Ts65Dn and Ts1Cje mouse lines: relevance for modeling down syndrome," Mammalian Genome, vol. 22, no. 11-12, pp. 674-684, 2011.

[28] L. G. Reinholdt, Y. Ding, G. T. Gilbert et al., "Molecular characterization of the translocation breakpoints in the Down syndrome mouse model Ts65Dn," Mammalian Genome, vol. 22, no. 11-12, pp. 685-691, 2011.

[29] Z. Li, T. Yu, M. Morishima et al., "Duplication of the entire 22.9 Mb human chromosome 21 syntenic region on mouse chromosome 16 causes cardiovascular and gastrointestinal abnormalities," Human Molecular Genetics, vol. 16, no. 11, pp. 1359-1366, 2007.

[30] P. L. Pereira, L. Magnol, I. Sahún et al., "A new mouse model for the trisomy of the Abcg1-U2af1 region reveals the complexity of the combinatorial genetic code of down syndrome," Human Molecular Genetics, vol. 18, no. 24, pp. 4756-4769, 2009.

[31] T. Yu, Z. Li, Z. Jia et al., "A mouse model of Down syndrome trisomic for all human chromosome 21 syntenic regions," Human Molecular Genetics, vol. 19, no. 14, pp. 2780-2791, 2010.

[32] A. O’Doherty, S. Ruf, C. Mulligan et al., "Genetics: an aneuploid mouse strain carrying human chromosome 21 with Down syndrome phenotypes," Science, vol. 309, no. 5743, pp. 2033-2037, 2005.

[33] B. T. Lamb, S. S. Sisodia, A. M. Lawler et al., "Introduction and expression of the 400 kilobase amyloid precursor protein gene in transgenic mice," Nature Genetics, vol. 5, pp. 22-30, 1993.

[34] D. J. Smith and E. M. Rubin, "Functional screening and complex traits: human 21q22.2 sequences affecting learning in mice," Human Molecular Genetics, vol. 6, no. 10, pp. 17291733, 1997.

[35] E. Morice, L. C. Andreae, S. F. Cooke et al., "Preservation of long-term memory and synaptic plasticity despite short-term impairments in the Tcl mouse model of down syndrome," Learning and Memory, vol. 15, no. 7, pp. 492-500, 2008.

[36] P. Papavassiliou, T. P. York, N. Gursoy et al., "The phenotype of persons having mosaicism for trisomy 21 /down syndrome reflects the percentage of trisomic cells present in different tissues," American Journal of Medical Genetics, Part A, vol. 149, no. 4, pp. 573-583, 2009.

[37] A. M. Lepagnol-Bestel, A. Zvara, G. Maussion et al., "DYRK1A interacts with the REST/NRSF-SWI/SNF chromatin remodelling complex to deregulate gene clusters involved in the neuronal phenotypic traits of Down syndrome," Human Molecular Genetics, vol. 18, no. 8, pp. 14051414, 2009.

[38] F. Mouton-Liger, S. Thomas, R. Rattenbach et al., "PCP4 (PEP19) overexpression induces premature neuronal differentiation associated with $\mathrm{Ca} 2+/$ Calmodulin-Dependent kinase II- $\delta$ activation in mouse models of down syndrome," Journal of Comparative Neurology, vol. 519, no. 14, pp. 27792802, 2011, Erratum in: Journal of Comparative Neurology, vol.519 no. 17, p. 3597, 2011.

[39] K. Amano, H. Sago, C. Uchikawa et al., "Dosage-dependent over-expression of genes in the trisomic region of Ts1 Cje mouse model for Down syndrome," Human Molecular Genetics, vol. 13, no. 13, pp. 1333-1340, 2004.

[40] N. Sahir, D. E. Brenneman, and J. M. Hill, "Neonatal mice of the Down syndrome model, Ts65Dn, exhibit upregulated VIP measures and reduced responsiveness of cortical astrocytes to VIP stimulation," Journal of Molecular Neuroscience, vol. 30, no. 3, pp. 329-340, 2006.

[41] C. Harashima, D. M. Jacobowitz, M. Stoffel et al., "Elevated expression of the G-protein-activated inwardly rectifying potassium channel 2 (GIRK2) in cerebellar unipolar brush cells of a Down syndrome mouse model," Cellular and Molecular Neurobiology, vol. 26, no. 4-6, pp. 719-734, 2006.

[42] F. Guedj, C. Sébrié, I. Rivals et al., "Green tea polyphenols rescue of brain defects induced by overexpression of DYRK1A," PLoS ONE, vol. 4, no. 2, article e4606, 2009.

[43] J. Braudeau, L. Dauphinot, A. Duchon et al., "Chronic treatment with a promnesiant GABA-A $\alpha 5$-selective inverse agonist increases immediate early genes expression during memory processing in mice and rectifies their expression levels in a Down syndrome mouse model," Advances in Pharmacological Sciences, vol. 2011, Article ID 153218, 11 pages, 2011.

[44] N. G. Saran, M. T. Pletcher, J. E. Natale, Y. Cheng, and R. H. Reeves, "Global disruption of the cerebellar transcriptome in a Down syndrome mouse model," Human Molecular Genetics, vol. 12, no. 16, pp. 2013-2019, 2003.

[45] D. M. Holtzman, D. Santucci, J. Kilbridge et al., "Developmental abnormalities and age-related neurodegeneration in a mouse model of Down syndrome," Proceedings of the National Academy of Sciences of the United States of America, vol. 93, no. 23, pp. 13333-13338, 1996.

[46] D. E. Kuhn, G. J. Nuovo, M. M. Martin et al., "Human chromosome 21-derived miRNAs are overexpressed in down 
syndrome brains and hearts," Biochemical and Biophysical Research Communications, vol. 370, no. 3, pp. 473-477, 2008.

[47] L. Toso, I. Cameroni, R. Roberson, D. Abebe, S. Bissell, and C. Y. Spong, "Prevention of developmental delays in a down syndrome mouse model," Obstetrics and Gynecology, vol. 112, no. 6, pp. 1242-1251, 2008.

[48] J. M. Hill, A. M. Ades, S. K. McCune et al., "Vasoactive intestinal peptide in the brain of a mouse model for Down syndrome," Experimental Neurology, vol. 183, no. 1, pp. 56$65,2003$.

[49] J. Lockrow, H. Boger, H. Bimonte-Nelson, and A. C. Granholm, "Effects of long-term memantine on memory and neuropathology in Ts65Dn mice, a model for Down syndrome," Behavioural Brain Research, vol. 221, no. 2, pp. 610-622, 2011.

[50] S. D. Ginsberg, M. J. Alldred, and S. Che, "Gene expression levels assessed by CA1 pyramidal neuron and regional hippocampal dissections in Alzheimer's disease," Neurobiology of Disease, vol. 45, no. 1, pp. 99-107, 2012.

[51] A. Salehi, J. D. Delcroix, P. V. Belichenko et al., "Increased App Expression in a Mouse Model of Down's Syndrome Disrupts NGF Transport and Causes Cholinergic Neuron Degeneration," Neuron, vol. 51, no. 1, pp. 29-42, 2006.

[52] A. Siddiqui, T. Lacroix, M. R. Stasko, J. J. Scott-McKean, A. C. S. Costa, and K. J. Gardiner, "Molecular responses of the Ts65Dn and Ts1Cje mouse models of Down syndrome to MK-801," Genes, Brain and Behavior, vol. 7, no. 7, pp. 810 $820,2008$.

[53] R. M. Escorihuela, I. F. Vallina, C. Martínez-Cué et al., "Impaired short- and long-term memory in Ts65Dn mice, a model for Down syndrome," Neuroscience Letters, vol. 247, no. 2-3, pp. 171-174, 1998.

[54] S. V. Voronov, S. G. Frere, S. Giovedi et al., "Synaptojanin 1-linked phosphoinositide dyshomeostasis and cognitive deficits in mouse models of Down's syndrome," Proceedings of the National Academy of Sciences of the United States of America, vol. 105, no. 27, pp. 9415-9420, 2008.

[55] M. P. Hunter, M. Nelson, M. Kurzer et al., "Intersectin 1 contributes to phenotypes in vivo: implications for Down's syndrome," NeuroReport, vol. 22, no. 15, pp. 767-772, 2011.

[56] G. Ermak, M. A. Pritchard, S. Dronjak, B. Niu, and K. J. A. Davies, "Do RCAN1 proteins link chronic stress with neurodegeneration?" FASEB Journal, vol. 25, no. 10, pp. 3306-3311, 2011.

[57] V. Régnier, J.-M. Billard, S. Gupta et al., "Brain phenotype of transgenic mice overexpressing cystathionine $\beta$-synthase," PLoS ONE, vol. 7, no. 1, Article ID e29056, 2012.

[58] K. Aldridge, R. H. Reeves, L. E. Olson, and J. T. Richtsmeier, "Differential effects of trisomy on brain shape and volume in related aneuploid mouse models," American Journal of Medical Genetics, Part A, vol. 143, no. 10, pp. 1060-1070, 2007.

[59] M. M. de Lagrán, R. Benavides-Piccione, I. Ballesteros-Yañez et al., "Dyrk1A influences neuronal morphogenesis through regulation of cytoskeletal dynamics in mammalian cortical neurons," Cerebral Cortex. In press.

[60] M. Álvarez, X. Estivill, and S. de la Luna, "DYRK1A accumulates in splicing speckles through a novel targeting signal and induces speckle disassembly," Journal of Cell Science, vol. 116, no. 15, pp. 3099-3107, 2003.

[61] J. Shi, T. Zhang, C. Zhou et al., "Increased dosage of Dyrk1A alters alternative splicing factor (ASF)-regulated alternative splicing of tau in down syndrome," Journal of Biological Chemistry, vol. 283, no. 42, pp. 28660-28669, 2008.
[62] D. Toiber, G. Azkona, S. Ben-Ari, N. Torán, H. Soreq, and M. Dierssen, "Engineering DYRK1A overdosage yields Down syndrome-characteristic cortical splicing aberrations," Neurobiology of Disease, vol. 40, no. 1, pp. 348-359, 2010.

[63] J. Wegiel, C. X. Gong, and Y. W. Hwang, "The role of DYRK1A in neurodegenerative diseases," FEBS Journal, vol. 278, no. 2, pp. 236-245, 2011.

[64] I. Ferrer, M. Barrachina, B. Puig et al., "Constitutive Dyrk1A is abnormally expressed in Alzheimer disease, Down syndrome, Pick disease, and related transgenic models," Neurobiology of Disease, vol. 20, no. 2, pp. 392-400, 2005.

[65] O. Sheppard, F. Plattner, A. Rubin et al., "Altered regulation of tau phosphorylation in a mouse model of down syndrome aging," Neurobiology of Aging, vol. 33, no. 4, pp. 828.e31828.e44, 2012.

[66] S. Bian and T. Sun, "Functions of noncoding RNAs in neural development and neurological diseases," Molecular Neurobiology, vol. 44, no. 3, pp. 359-373, 2011.

[67] T. S. Elton, S. E. Sansom, and M. M. Martin, "Trisomy21 gene dosage overexpression of miRNAs results in the haploinsufficiency of specific target proteins," RNA Biology, vol. 7, no. 5, pp. 540-547, 2010.

[68] Y. Y. Li, P. N. Alexandrov, A. I. Pogue, Y. Zhao, S. Bhattacharjee, and W. J. Lukiw, "miRNA-155 upregulation and complement factor $\mathrm{H}$ deficits in Down's syndrome," Neuroreport, vol. 23, no. 3, pp. 168-173, 2012.

[69] D. E. Kuhn, G. J. Nuovo, A. V. Terry et al., "Chromosome 21derived microRNAs provide an etiological basis for aberrant protein expression in human down syndrome brains," Journal of Biological Chemistry, vol. 285, no. 2, pp. 1529-1543, 2010.

[70] A. I. Pogue, J. G. Cui, Y. Y. Li, Y. Zhao, F. Culicchia, and W. J. Lukiw, "Micro RNA-125b (miRNA-125b) function in astrogliosis and glial cell proliferation," Neuroscience Letters, vol. 476, no. 1, pp. 18-22, 2010.

[71] G. Pollonini, V. Gao, A. Rabe, S. Palminiello, G. Albertini, and C. M. Alberini, "Abnormal expression of synaptic proteins and neurotrophin-3 in the down syndrome mouse model Ts65Dn," Neuroscience, vol. 156, no. 1, pp. 99-106, 2008.

[72] S. Trazzi, V. M. Mitrugno, E. Valli et al., "APP-dependent up-regulation of Ptch1 underlies proliferation impairment of neural precursors in Down syndrome," Human Molecular Genetics, vol. 20, no. 8, pp. 1560-1573, 2011.

[73] T. K. Best, N. P. Cramer, L. Chakrabarti, T. F. Haydar, and Z. Galdzicki, "Dysfunctional hippocampal inhibition in the Ts65Dn mouse model of Down syndrome," Experimental Neurology, vol. 233, no. 2, pp. 749-757, 2012.

[74] M. A. Cortez, L. Shen, Y. Wu et al., "Infantile spasms and Down syndrome: a new animal model," Pediatric Research, vol. 65, no. 5, pp. 499-503, 2009.

[75] P. Bianchi, E. Ciani, S. Guidi et al., "Early pharmacotherapy restores neurogenesis and cognitive performance in the Ts65Dn mouse model for down syndrome," Journal of Neuroscience, vol. 30, no. 26, pp. 8769-8779, 2010.

[76] R. Roberson, L. Toso, D. Abebe, and C. Y. Spong, "Altered expression of KIF17, a kinesin motor protein associated with NR2B trafficking, may mediate learning deficits in a Down syndrome mouse model," American Journal of Obstetrics and Gynecology, vol. 198, no. 3, pp. 313.e1-313.e4, 2008.

[77] R. J. Siarey, A. Kline-Burgess, M. Cho et al., "Altered signaling pathways underlying abnormal hippocampal synaptic plasticity in the Ts65Dn mouse model of Down syndrome," Journal of Neurochemistry, vol. 98, no. 4, pp. 1266-1277, 
2006, Erratum in: Journal of Neurochemistry, vol. 99, no. 4. p. 1320, 2006.

[78] H. Seo and O. Isacson, "Abnormal APP, cholinergic and cognitive function in Ts65Dn Down's model mice," Experimental Neurology, vol. 193, no. 2, pp. 469-480, 2005.

[79] S. Gotti, S. Chiavegatto, M. Sica, C. Viglietti-Panzica, R. J. Nelson, and G. Panzica, "Alteration of NO-producing system in the basal forebrain and hypothalamus of Ts65Dn mice: an immunohistochemical and histochemical study of a murine model for Down syndrome," Neurobiology of Disease, vol. 16, no. 3, pp. 563-571, 2004.

[80] D. Pérez-Cremades, S. Hernández, J. M. Blasco-Ibáñez, C. Crespo, J. Nacher, and E. Varea, "Alteration of inhibitory circuits in the somatosensory cortex of Ts65Dn mice, a model for Down's syndrome," Journal of Neural Transmission, vol. 117, no. 4, pp. 445-455, 2010.

[81] M. Millan Sanchez, S. N. Heyn, D. Das, S. Moghadam, K. J. Martin, and A. Salehi, "Neurobiological elements of cognitive dysfunction in down syndrome: exploring the role of APP," Biological Psychiatry, vol. 71, no. 5, pp. 403-409, 2012.

[82] C. L. Hunter, D. Bachman, and A. C. Granholm, "Minocycline prevents cholinergic loss in a mouse model of Down's syndrome," Annals of Neurology, vol. 56, no. 5, pp. 675-688, 2004.

[83] A. Contestabile, T. Fila, R. Bartesaghi, A. Contestabile, and E. Ciani, "Choline acetyltransferase activity at different ages in brain of Ts65Dn mice, an animal model for Down's syndrome and related neurodegenerative diseases," Journal of Neurochemistry, vol. 97, no. 2, pp. 515-526, 2006.

[84] J. D. Cooper, A. Salehi, J. D. Delcroix et al., "Failed retrograde transport of NGF in a mouse model of Down's syndrome: reversal of cholinergic neurodegenerative phenotypes following NGF infusion," Proceedings of the National Academy of Sciences of the United States of America, vol. 98, no. 18, pp. 10439-10444, 2001.

[85] D. Necchi, S. Lomoio, and E. Scherini, "Axonal abnormalities in cerebellar Purkinje cells of the Ts65Dn mouse," Brain Research, vol. 1238, pp. 181-188, 2008.

[86] S. Lomoio, E. Scherini, and D. Necchi, “ $\beta$-Amyloid overload does not directly correlate with SAPK/JNK activation and tau protein phosphorylation in the cerebellar cortex of Ts65Dn mice," Brain Research, vol. 1297, pp. 198-206, 2009.

[87] Y. Chen, V. V. Dyakin, C. A. Branch et al., "In vivo MRI identifies cholinergic circuitry deficits in a Down syndrome model," Neurobiology of Aging, vol. 30, no. 9, pp. 1453-1465, 2009.

[88] H. Seo and O. Isacson, "The hAPP-YAC transgenic model has elevated UPS activity in the frontal cortex similar to Alzheimer's disease and Down's syndrome," Journal of Neurochemistry, vol. 114, no. 6, pp. 1819-1826, 2010.

[89] J. M. Delabar, R. Aflalo-Rattenbac, and N. Créau, "Developmental defects in trisomy 21 and mouse models," TheScientificWorldJournal, vol. 6, pp. 1945-1964, 2006.

[90] I. T. Lott and M. Dierssen, "Cognitive deficits and associated neurological complications in individuals with Down's syndrome," The Lancet Neurology, vol. 9, no. 6, pp. 623-633, 2010.

[91] K. Ishihara, K. Amano, E. Takaki et al., "Enlarged brain ventricles and impaired neurogenesis in the Ts1Cje and Ts2Cje mouse models of down syndrome," Cerebral Cortex, vol. 20, no. 5, pp. 1131-1143, 2010.

[92] L. E. Olson, R. J. Roper, L. L. Baxter, E. J. Carlson, C. J. Epstein, and R. H. Reeves, "Down syndrome mouse models Ts65Dn, Ts1Cje, and Ms1Cje/Ts65Dn exhibit variable severity of cerebellar phenotypes," Developmental Dynamics, vol. 230, no. 3, pp. 581-589, 2004.

[93] H. A. Lorenzi and R. H. Reeves, "Hippocampal hypocellularity in the Ts65Dn mouse originates early in development," Brain Research, vol. 1104, no. 1, pp. 153-159, 2006.

[94] L. Chakrabarti, Z. Galdzicki, and T. F. Haydar, "Defects in embryonic neurogenesis and initial synapse formation in the forebrain of the Ts65Dn mouse model of Down syndrome," Journal of Neuroscience, vol. 27, no. 43, pp. 11483-11495, 2007.

[95] L. Chakrabarti, T. K. Best, N. P. Cramer et al., "Olig1 and Olig2 triplication causes developmental brain defects in Down syndrome," Nature Neuroscience, vol. 13, no. 8, pp. 927-934, 2010.

[96] S. Guidi, E. Ciani, P. Bonasoni, D. Santini, and R. Bartesaghi, "Widespread proliferation impairment and hypocellularity in the cerebellum of fetuses with down syndrome," Brain Pathology, vol. 21, no. 4, pp. 361-373, 2011.

[97] R. J. Roper, L. L. Baxter, N. G. Saran, D. K. Klinedinst, P. A. Beachy, and R. H. Reeves, "Defective cerebellar response to mitogenic Hedgehog signaling in Down's syndrome mice," Proceedings of the National Academy of Sciences of the United States of America, vol. 103, no. 5, pp. 1452-1456, 2006, Erratum in: Proceedings of the National Academy of Sciences of the United States of America, vol. 103, no. 13, p. 5242, 2006.

[98] R. J. Roper, J. F. VanHorn, C. C. Cain, and R. H. Reeves, "A neural crest deficit in Down syndrome mice is associated with deficient mitotic response to Sonic hedgehog," Mechanisms of Development, vol. 126, no. 3-4, pp. 212-219, 2009.

[99] R. C. von Rotz, B. M. Kohli, J. Bosset et al., "The APP intracellular domain forms nuclear multiprotein complexes and regulates the transcription of its own precursor," Journal of Cell Science, vol. 117, no. 19, pp. 4435-4448, 2004.

[100] D. Satgé, A. J. Sasco, N. L. T. Carlsen et al., "A lack of neuroblastoma in Down syndrome: a study from 11 European countries," Cancer Research, vol. 58, no. 3, pp. 448452, 1998.

[101] D. Satgé, D. Sommelet, A. Geneix, M. Nishi, P. Malet, and M. Vekemans, "A tumor profile in Down syndrome," American Journal of Medical Genetics, vol. 78, no. 3, pp. 207-216, 1998.

[102] D. Satgé and C. H. Rickert, "A medical enigma: persons with down syndrome do not develop medulloblastoma," Neuroepidemiology, vol. 32, no. 2, p. 164, 2009.

[103] J. Park, Y. Oh, L. Yoo et al., "Dyrk1A phosphorylates p53 and inhibits proliferation of embryonic neuronal cells," Journal of Biological Chemistry, vol. 285, no. 41, pp. 31895-31906, 2010.

[104] A. Contestabile, T. Fila, R. Bartesaghi, and E. Ciani, "Cell cycle elongation impairs proliferation of cerebellar granule cell precursors in the Ts65Dn mouse, an animal model for down syndrome," Brain Pathology, vol. 19, no. 2, pp. 224237, 2009.

[105] B. Hämmerle, E. Ulin, J. Guimera, W. Becker, F. Guillemot, and F. J. Tejedor, "Transient expression of Mnb/dyrkla couples cell cycle exit and differentiation of neuronal precursors by inducing p27KIP1 expression and suppressing NOTCH signaling," Development, vol. 138, no. 12, pp. 2543-2554, 2011.

[106] O. Ayrault, F. Zindy, J. Rehg, C. J. Sherr, and M. F. Roussel, "Two tumor suppressors, p27Kip1 and Patched-1, collaborate to prevent medulloblastoma," Molecular Cancer Research, vol. 7, no. 1, pp. 33-40, 2009.

[107] O. Yabut, J. Domogauer, and G. D’Arcangelo, "Dyrk1A overexpression inhibits proliferation and induces premature 
neuronal differentiation of neural progenitor cells," Journal of Neuroscience, vol. 30, no. 11, pp. 4004-4014, 2010.

[108] D. Satgé, N. Créau, R. Aflalo-Rattenbach, S. Ducassou, P. Lutz, and J. Bénard, "Down syndrome's protection against neuroblastoma: the stromal and neural overmaturation tracks," in Focus on Neuroblastoma Research, F. Columbus, Ed., chapter 3, pp. 57-100, Nova Science, New York, NY, USA, 2008.

[109] S. I. Harashima, Y. Wang, T. Horiuchi, Y. Seino, and $\mathrm{N}$. Inagaki, "Purkinje cell protein 4 positively regulates neurite outgrowth and neurotransmitter release," Journal of Neuroscience Research, vol. 89, no. 10, pp. 1519-1530, 2011.

[110] J. A. Golden and B. T. Hyman, "Development of the superior temporal neocortex is anomalous in trisomy 21," Journal of Neuropathology and Experimental Neurology, vol. 53, no. 5, pp. 513-520, 1994.

[111] N. Rueda, R. Mostany, A. Pazos, J. Flórez, and C. MartínezCué, "Cell proliferation is reduced in the dentate gyrus of aged but not young Ts65Dn mice, a model of Down syndrome," Neuroscience Letters, vol. 380, no. 1-2, pp. 197201, 2005.

[112] S. Clark, J. Schwalbe, M. R. Stasko, P. J. Yarowsky, and A. C. S. Costa, "Fluoxetine rescues deficient neurogenesis in hippocampus of the Ts65Dn mouse model for Down syndrome," Experimental Neurology, vol. 200, no. 1, pp. 256261, 2006.

[113] J. A. Troca-Marín, A. Alves-Sampaio, and M. L. Montesinos, "An increase in basal BDNF provokes hyperactivation of the Akt-Mammalian target of rapamycin pathway and deregulation of local dendritic translation in a mouse model of down's syndrome," Journal of Neuroscience, vol. 31, no. 26, pp. 9445 9455, 2011.

[114] H. A. Bimonte-Nelson, C. L. Hunter, M. E. Nelson, and A. C. E. Granholm, "Frontal cortex BDNF levels correlate with working memory in an animal model of Down syndrome," Behavioural Brain Research, vol. 139, no. 1-2, pp. 47-57, 2003.

[115] G. Dogliotti, E. Galliera, F. Licastro, and M. M. Corsi, "Agerelated changes in plasma levels of BDNF in Down syndrome patients," Immunity and Ageing, vol. 7, article 2, 2010.

[116] A. Alves-Sampaio, J. A. Troca-Marín, and M. L. Montesinos, "NMDA-Mediated regulation of DSCAM dendritic local translation is lost in a mouse model of Down's syndrome," Journal of Neuroscience, vol. 30, no. 40, pp. 13537-13548, 2010.

[117] S. Bahn, M. Mimmack, M. Ryan et al., "Neuronal target genes of the neuron-restrictive silencer factor in neurospheres derived from fetuses with Down's syndrome: a gene expression study," Lancet, vol. 359, no. 9303, pp. 310-315, 2002.

[118] C. Canzonetta, C. Mulligan, S. Deutsch et al., "DYRK1Adosage imbalance perturbs NRSF/REST levels, deregulating pluripotency and embryonic stem cell fate in Down syndrome," American Journal of Human Genetics, vol. 83, no. 3, pp. 388-400, 2008.

[119] S. Takashima, L. E. Becker, D. L. Armstrong, and F. W. Chan, "Abnormal neuronal development in the visual cortex of the human fetus and infant with Down's syndrome. A quantitative and qualitative Golgi study," Brain Research, vol. 225, no. 1, pp. 1-21, 1981.

[120] L. E. Becker, D. L. Armstrong, and F. Chan, "Dendritic atrophy in children with Down's syndrome," Annals of Neurology, vol. 20, no. 4, pp. 520-526, 1986.

[121] M. Dierssen, R. Benavides-Piccione, C. Martínez-Cué et al., "Alterations of neocortical pyramidal cell phenotype in the Ts65Dn mouse model of Down syndrome: effects of environmental enrichment," Cerebral Cortex, vol. 13, no. 7, pp. 758-764, 2003.

[122] A. M. Kleschevnikov, P. V. Belichenko, A. J. Villar, C. J. Epstein, R. C. Malenka, and W. C. Mobley, "Hippocampal long-term potentiation suppressed by increased inhibition in the Ts65Dn mouse, a genetic model of down syndrome," Journal of Neuroscience, vol. 24, no. 37, pp. 8153-8160, 2004.

[123] F. Fernandez, W. Morishita, E. Zuniga et al., "Pharmacotherapy for cognitive impairment in a mouse model of Down syndrome," Nature Neuroscience, vol. 10, no. 4, pp. 411-413, 2007.

[124] P. V. Belichenko, E. Masliah, A. M. Kleschevnikov et al., "Synaptic structural abnormalities in the Ts65Dn mouse model of Down syndrome," Journal of Comparative Neurology, vol. 480, no. 3, pp. 281-298, 2004.

[125] P. V. Belichenko, A. M. Kleschevnikov, E. Masliah et al., "Excitatory-inhibitory relationship in the fascia dentata in the Ts65Dn mouse model of down syndrome," Journal of Comparative Neurology, vol. 512, no. 4, pp. 453-466, 2009.

[126] A. M. Kleschevnikov, P. V. Belichenko, J. Gall et al., "Increased efficiency of the GABAA and GABAB receptor-mediated neurotransmission in the Ts65Dn mouse model of Down syndrome," Neurobiology of Disease, vol. 45, no. 2, pp. 683691, 2012.

[127] M. Di Filippo, A. Tozzi, V. Ghiglieri et al., "Impaired plasticity at specific subset of striatal synapses in the Ts65Dn mouse model of Down syndrome," Biological Psychiatry, vol. 67, no. 7, pp. 666-671, 2010.

[128] N. Rueda, M. Llorens-Martín, J. Flórez et al., "Memantine normalizes several phenotypic features in the Ts65Dn mouse model of down syndrome," Journal of Alzheimer's Disease, vol. 21, no. 1, pp. 277-290, 2010.

[129] T. K. Best, R. J. Siarey, and Z. Galdzicki, "Ts65Dn, a mouse model of down syndrome, exhibits increased GABA Binduced potassium current," Journal of Neurophysiology, vol. 97, no. 1, pp. 892-900, 2007.

[130] C. L. Maire, A. Wegener, C. Kerninon, and B. N. Oumesmar, "Gain-of-function of olig transcription factors enhances oligodendrogenesis and myelination," Stem Cells, vol. 28, no. 9, pp. 1611-1622, 2010.

[131] A. Salehi, M. Faizi, D. Colas et al., "Restoration of norepinephrine-modulated contextual memory in a mouse model of Down syndrome," Science Translational Medicine, vol. 1, no. 7, p. 7ra17, 2009.

[132] S. Hernández, J. Gilabert-Juan, J. M. Blasco-Ibáñez, C. Crespo, J. Nácher, and E. Varea, "Altered expression of neuropeptides in the primary somatosensory cortex of the Down syndrome model Ts65Dn," Neuropeptides, vol. 46, no. 1, pp. 29-37, 2012.

[133] F. Fernandez, J. C. Trinidad, M. Blank, D. D. Feng, A. L. Burlingame, and C. C. Garner, "Normal protein composition of synapses in Ts65Dn mice: a mouse model of Down syndrome," Journal of Neurochemistry, vol. 110, no. 1, pp. 157-169, 2009.

[134] P. V. Belichenko, A. M. Kleschevnikov, A. Salehi, C. J. Epstein, and W. C. Mobley, "Synaptic and cognitive abnormalities in mouse models of Down syndrome: exploring genotypephenotype relationships," Journal of Comparative Neurology, vol. 504, no. 4, pp. 329-345, 2007.

[135] P. V. Belichenko, A. M. Kleschevnikov, E. Masliah et al., "Excitatory-inhibitory relationship in the fascia dentata in the Ts65Dn mouse model of down syndrome," Journal of Comparative Neurology, vol. 512, no. 4, pp. 453-466, 2009. 
[136] M. Ayberk Kurt, D. Ceri Davies, M. Kidd, M. Dierssen, and J. Flórez, "Synaptic deficit in the temporal cortex of partial trisomy 16 (Ts65Dn) mice," Brain Research, vol. 858, no. 1, pp. 191-197, 2000.

[137] M. A. Kurt, M. I. Kafa, M. Dierssen, and D. C. Davies, "Deficits of neuronal density in CA1 and synaptic density in the dentate gyrus, CA3 and CA1, in a mouse model of Down syndrome," Brain Research, vol. 1022, no. 1-2, pp. 101-109, 2004.

[138] N. P. Belichenko, P. V. Belichenko, A. M. Kleschevnikov, A. Salehi, R. H. Reeves, and W. C. Mobley, "The "Down syndrome critical region" is sufficient in the mouse model to confer behavioral, neurophysiological, and synaptic phenotypes characteristic of Down syndrome," Journal of Neuroscience, vol. 29, no. 18, pp. 5938-5948, 2009.

[139] J. P. O’Bryan, "Intersecting pathways in cell biology," Science Signaling, vol. 3, no. 152, article re10, 2010.

[140] Y. Kim, J. Park, W. J. Song, and S. Chang, "Overexpression of Dyrk1A causes the defects in synaptic vesicle endocytosis," NeuroSignals, vol. 18, no. 3, pp. 164-172, 2011.

[141] M. Mani, S. Y. Lee, L. Lucast et al., "The dual phosphatase activity of synaptojanin 1 is required for both efficient synaptic vesicle endocytosis and reavailability at nerve terminals," Neuron, vol. 56, no. 6, pp. 1004-1018, 2007.

[142] D. E. Berman, C. Dall'Armi, S. V. Voronov et al., "Oligomeric amyloid- $\beta$ peptide disrupts phosphatidylinositol-4,5- bisphosphate metabolism," Nature Neuroscience, vol. 11, no. 5, pp. 547-554, 2008.

[143] S. Guidi, P. Bonasoni, C. Ceccarelli et al., "Neurogenesis impairment and increased cell death reduce total neuron number in the hippocampal region of fetuses with Down syndrome," Brain Pathology, vol. 18, no. 2, pp. 180-197, 2008.

[144] G. Zdaniuk, T. Wierzba-Bobrowicz, G. M. Szpak, and T. Stępień, "Astroglia disturbances during development of the central nervous system in fetuses with Down's syndrome," Folia Neuropathologica, vol. 49, no. 2, pp. 109-114, 2011.

[145] R. X. Moldrich, L. Dauphinot, J. Laffaire et al., "Proliferation deficits and gene expression dysregulation in Down's syndrome (Ts1Cje) neural progenitor cells cultured from neurospheres," Journal of Neuroscience Research, vol. 87, no. 14, pp. 3143-3152, 2009.

[146] F. Herrera, Q. Chen, W. H. Fischer, P. Maher, and D. R. Schubert, "Synaptojanin-1 plays a key role in astrogliogenesis: possible relevance for Down's syndrome," Cell Death and Differentiation, vol. 16, no. 6, pp. 910-920, 2009.

[147] C. A. Hewitt, K. H. Ling, T. D. Merson et al., "Gene network disruptions and neurogenesis defects in the adult Ts1Cje mouse model of down syndrome," PLoS ONE, vol. 5, no. 7, Article ID e11561, 2010.

[148] J. Lu, G. Esposito, C. Scuderi et al., "S100B and APP promote a gliocentric shift and impaired neurogenesis in down syndrome neural progenitors," PLoS ONE, vol. 6, no. 7, Article ID e22126, 2011.

[149] A. Contestabile, T. Fila, C. Ceccarelli et al., "Cell cycle alteration and decreased cell proliferation in the hippocampal dentate gyrus and in the neocortical germinal matrix of fetuses with down syndrome and in Ts65Dn mice," Hippocampus, vol. 17, no. 8, pp. 665-678, 2007.

[150] A. W. Vorbrodt, S. Li, W. T. Brown, and N. Ramakrishna, "Increased expression of $\beta$-catenin in brain microvessels of a segmentally trisomic (Ts65Dn) mouse model of Down syndrome," Brain Cell Biology, vol. 36, no. 5-6, pp. 203-211, 2008 .
[151] N. Ramakrishna, H. C. Meeker, S. Li, W. T. Brown, R. Rao, and A. El Idrissi, "Upregulation of $\beta$-catenin expression in down syndrome model Ts65Dn mouse brain," Neuroscience, vol. 161, no. 2, pp. 451-458, 2009.

[152] A. S. Karlsen and B. Pakkenberg, "Total numbers of neurons and glial cells in cortex and basal ganglia of aged brains with down syndrome-a stereological study," Cerebral Cortex, vol. 21, no. 11, pp. 2519-2524, 2011.

[153] J. A. Colombo, H. D. Reisin, M. Jones, and C. Bentham, "Development of interlaminar astroglial processes in the cerebral cortex of control and Down's syndrome human cases," Experimental Neurology, vol. 193, no. 1, pp. 207-217, 2005.

[154] A. Rovelet-Lecrux, D. Hannequin, G. Raux et al., "APP locus duplication causes autosomal dominant early-onset Alzheimer disease with cerebral amyloid angiopathy," Nature Genetics, vol. 38, no. 1, pp. 24-26, 2006.

[155] J. Braudeau, B. Delatour, A. Duchon et al., "Specific targeting of the GABA-A receptor $\alpha 5$ subtype by a selective inverse agonist restores cognitive deficits in Down syndrome mice," Journal of Psychopharmacology, vol. 25, no. 8, pp. 1030-1042, 2011.

[156] C. Martínez-Cué, C. Baamonde, M. Lumbreras et al., "Differential effects of environmental enrichment on behavior and learning of male and female Ts65Dn mice, a model for Down syndrome," Behavioural Brain Research, vol. 134, no. 1-2, pp. 185-200, 2002.

[157] T. Begenisic, M. Spolidoro, C. Braschi et al., "Environmental enrichment decreases GABAergic inhibition and improves cognitive abilities, synaptic plasticity, and visual functions in a mouse model of Down syndrome," Frontiers in Cellular Neuroscience. In press.

[158] Delabar, J. M. Guedj, F. Luilier et al., Program No. 402.6, PGT Improves Learning and Synaptic Plasticity Markers in Ts65Dn Mouse Model of Down Syndrome, Neuroscience Meeting Planner, Society for Neuroscience, Washington, DC, USA, 2010 . 

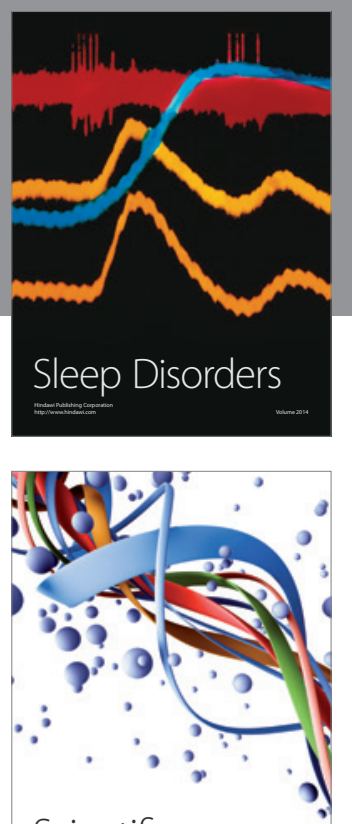

Scientifica
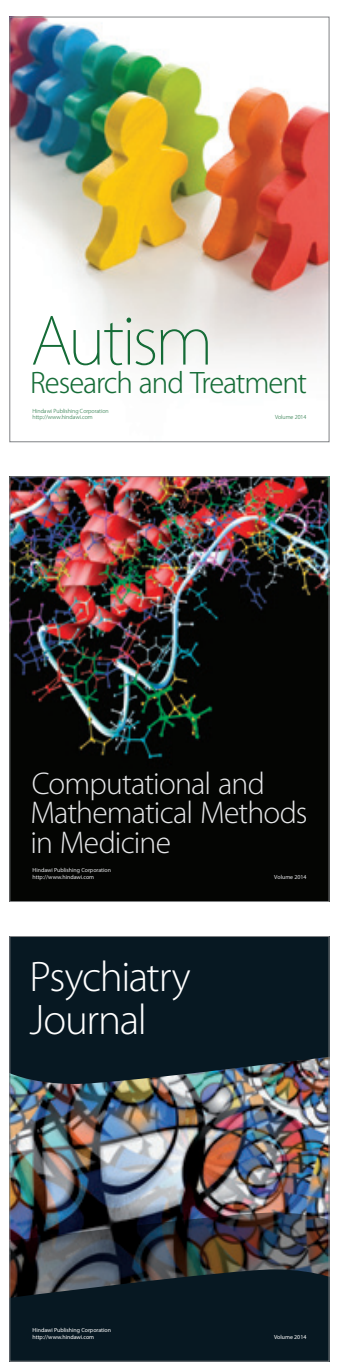
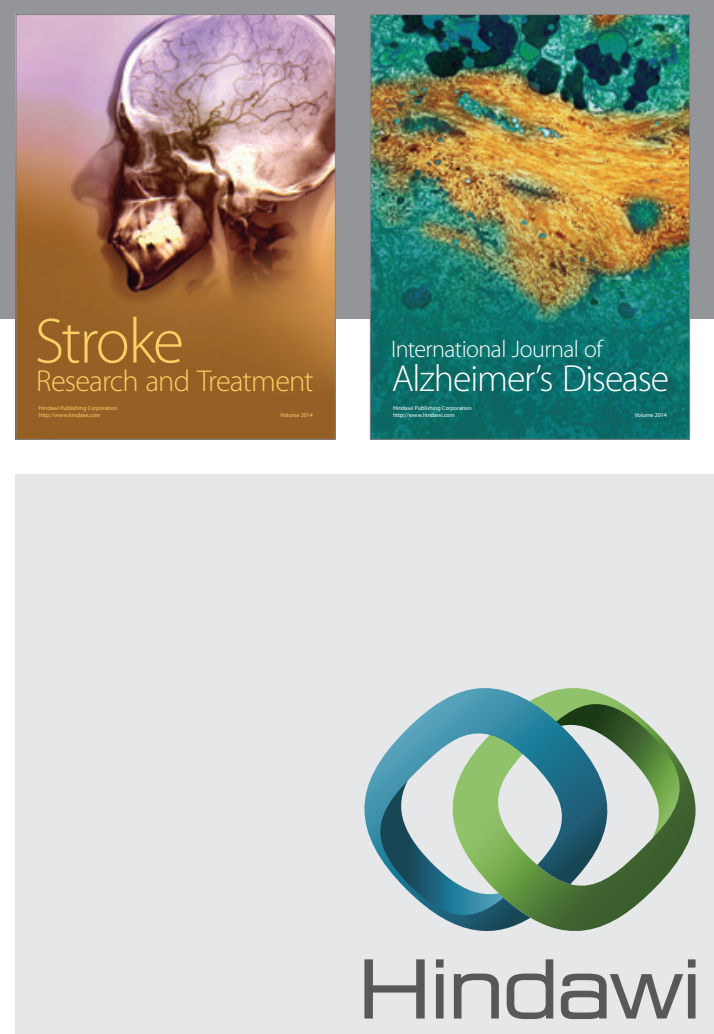

Submit your manuscripts at

http://www.hindawi.com
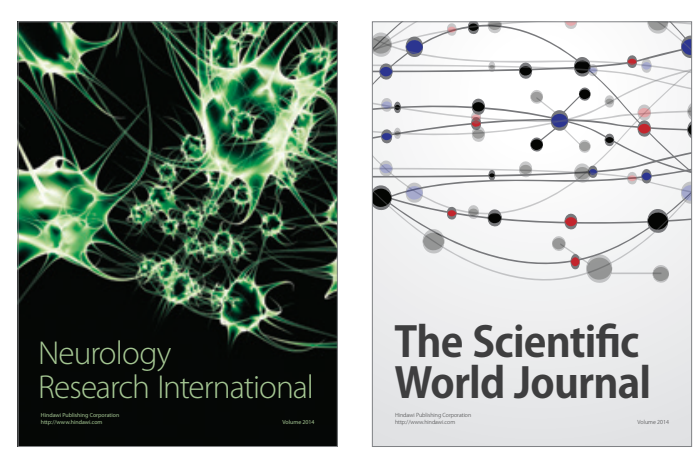

The Scientific World Journal

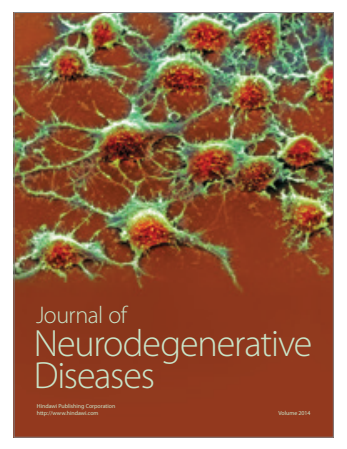

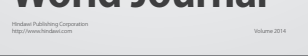

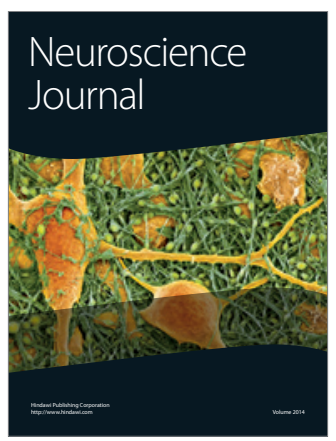

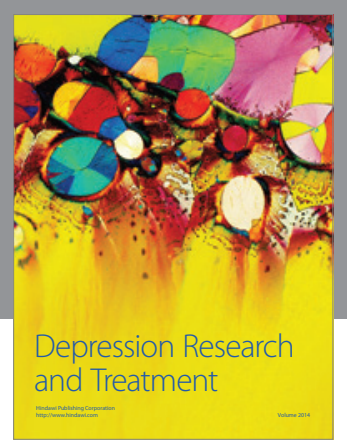
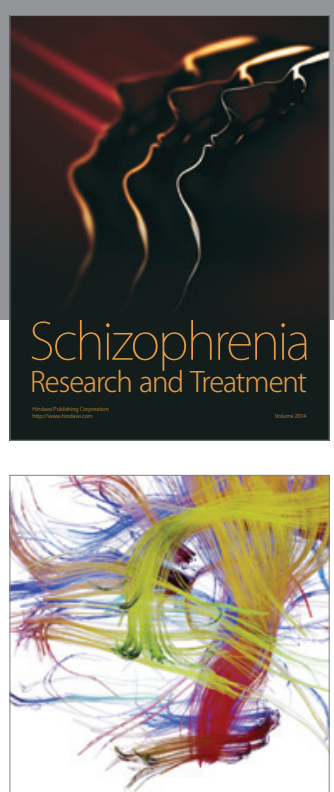

Brain Science

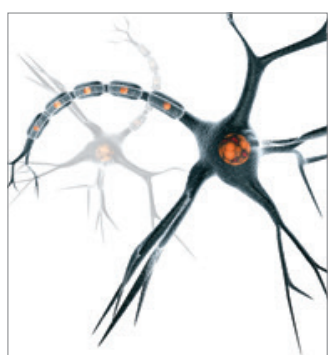

Neural Plasticity
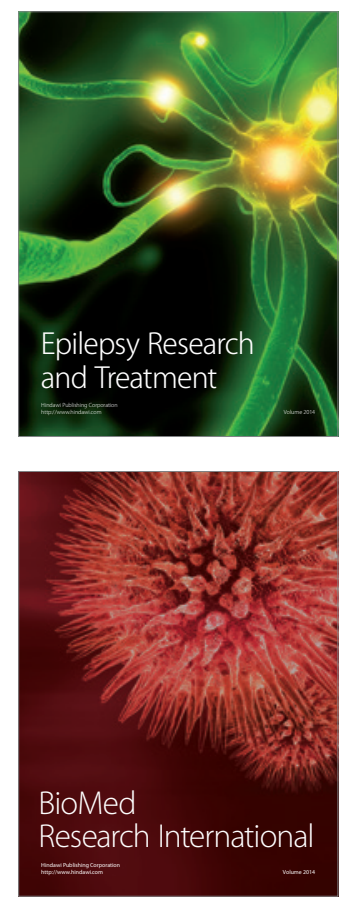

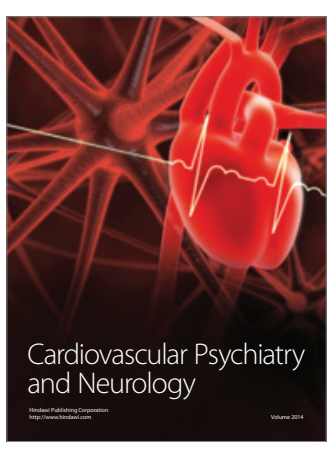

Parkinson's

Disease
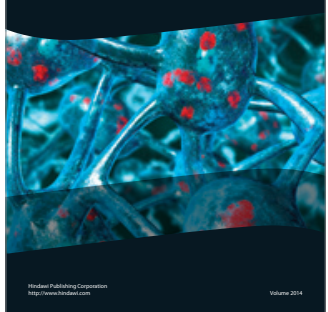